\title{
Ground level concentration of some air pollutants from Nigeria thermal power plants
}

\author{
A. J. Adesanmi, J. A. Adeniran, B. S. Fakinle, L. A. Jimoda, R.O. Yusuf \& J. A. \\ Sonibare
}

To cite this article: A. J. Adesanmi, J. A. Adeniran, B. S. Fakinle, L. A. Jimoda, R.O. Yusuf \& J. A. Sonibare (2016) Ground level concentration of some air pollutants from Nigeria thermal power plants, Energy Sources, Part A: Recovery, Utilization, and Environmental Effects, 38:16, 2426-2432

To link to this article: http://dx.doi.org/10.1080/15567036.2015.1081996

Submit your article to this journal $\llbracket$

a

View related articles \lceil

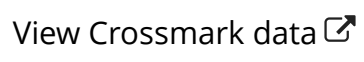




\title{
Ground level concentration of some air pollutants from Nigeria thermal power plants
}

\author{
A. J. Adesanmi ${ }^{a}$, J. A. Adeniran ${ }^{\text {, }}$ B. S. Fakinle $\mathbb{E}^{c}$, L. A. Jimodad ${ }^{\text {, R.O. Yusuf }}{ }^{b}$, \\ and J. A. Sonibare ${ }^{a}$ \\ ${ }^{a}$ Environmental Engineering Research Laboratory, Department of Chemical Engineering, Obafemi Awolowo \\ University, lle-Ife, Nigeria; ${ }^{b}$ Environmental Engineering Research Laboratory, Department of Chemical Engineering, \\ University of Ilorin, Ilorin, Nigeria; 'Department of Chemical Engineering, Landmark University, Omu-Aran, Nigeria; \\ dDepartment of Chemical Engineering, Ladoke Akintola University of Technology, Ogbomoso, Nigeria
}

\begin{abstract}
Power sector in Nigeria is undergoing structural reforms aimed at improving and expanding the current generation capacity, using thermal power plants. Ground level concentrations of air pollutants emitted from natural gas-powered thermal power plants were estimated using the American Meteorological Society-Environmental Protection Agency Regulatory Model (AERMOD). The average 24-h ground level concentrations of CO, $\mathrm{NO}_{x}, \mathrm{SO}_{2}$, particulate matter (PM), and volatile organic compounds (VOCs) were $31.88-72.79 ; 61.33-104 ; 0.61-3.91 ; 0.21-1.52$; and $0.19-1.09 \mu \mathrm{g} / \mathrm{m}^{3}$, respectively. There is need for continuous monitoring of ground level concentration of pollutants around the thermal power plants to guarantee the safety of the environment in the host communities.
\end{abstract}

\section{KEYWORDS}

Air pollutants; air quality; dispersion; emissions; power plants

\section{Introduction}

Nigeria's electric power sector requires substantial reform to realize the country's economic development and poverty alleviation targets. Industries rely on backup electric power generators for their businesses, thereby increasing their operating and capital costs (Sonibare et al., 2014). Substantial expansion in quantity, quality, and access to infrastructure services, especially electricity, is fundamental to rapid and sustained economic growth, and poverty reduction. The country is developing the strategy that would make electricity available at a sufficient level to meet up with the ever increasing energy demand (Sonibare, 2010).

Generally, electricity demand in Nigeria far outstrips the supply and the supply is epileptic in nature. For over two decades (1980s-2000s), the generation capacity in the country was less than half installed capacity (Essien and Igweonu, 2014). The total generation capacity for the period of 1980-2009 ranged from 783.9 to $4076.2 \mathrm{MW}$ while the installed capacity ranged from 2,507 to 8702.25 MW (Olugbenga et al., 2013).

To reform the power sector in Nigeria, the generation capacity and distribution network have to be expanded. For improved energy generation in the country, thermal electric plants that burn fossil fuels (natural gas) to generate electricity are being adopted. However, these also generate air emissions, which are of great concern (Kouprianov et al., 2002; Pokale, 2012). Major components of these emissions are air pollutants including carbon monoxide $(\mathrm{CO})$, oxides of nitrogen $\left(\mathrm{NO}_{x}\right)$, particulate matter $(\mathrm{PM})$, sulfur dioxide $\left(\mathrm{SO}_{2}\right)$, and volatile organic compounds (VOCs), the focus of this study. This paper investigates the ground level concentrations of air pollutants associated with emissions from thermal electric power plants in Nigeria and their substantial contribution to degraded air quality.

CONTACT J.A. Adeniran adeniran.ja@unilorin.edu.ng Environmental Engineering Research Laboratory, Department of Chemical Engineering, University of Ilorin, 240003, Nigeria.

Color versions of one or more of the figures in the article can be found online at www.tandfonline.com/ueso.

(c) 2016 Taylor \& Francis Group, LLC 


\section{Methodology}

The study carried out dispersion modeling on the existing thermal power plants in Nigeria (Table 1) using the American Meteorological Society-Environmental Protection Agency Regulatory Model (AERMOD). The AERMOD View is a complete and powerful air dispersion modeling package which seamlessly incorporates the following popular U.S. environmental protection agency (EPA) air dispersion models into one integrated interface. The activities involved here are the combustion of natural gas in the plant for electric power generation, emissions from the thermal power plants (Eq. (1)) were adopted with the worse-case scenario, assuming no control.

An average consumption rate of natural gas in thermal power plants was taken to be $0.39 \mathrm{MMScf}$ per day per MW (Sonibare and Akeredolu, 2006). This is an equivalent of $11043.57 \mathrm{~m}^{3} /$ day of natural gas. Emission factors of stationary gas turbines for electricity generation as (Table 2) AP-42 of the United States EPA (1995) was used to estimate the emission rate of criteria air pollutants from thermal power plants.

Emission inventory was calculated (Eq. (1)) using Emission factors of stationary gas turbines for the electricity generation approach as (Table 2) of AP-42 of the United States EPA (1995). Meteorological data were obtained for the study area. Activity data usually give a measure of the scale of activity causing the emissions which is the fuel (natural gas) consumption rate (MMScf). A complete inventory typically contains all regulated pollutants (EPA, 1995), and their information is useful to elaborate a map showing the geographic distribution of emissions.

Emission rates of air pollutants are estimated using Eq. (1).

$$
E=A \times E F,
$$

where

$E=$ emissions rate in units of pollutant per unit of time $(\mathrm{g} / \mathrm{s})$

$A=$ activity rate, in units of weight, volume, distance or duration per unit of time $\left(\mathrm{m}^{3} / \mathrm{s}\right)$

$\mathrm{EF}=$ emission factor, in pollutant per unit of weight, volume distance or duration $\left(\mathrm{g} / \mathrm{m}^{3}\right)$.

Table 1. Some of the existing thermal power plants in Nigeria.

\begin{tabular}{|c|c|c|c|c|c|c|}
\hline \multirow[b]{2}{*}{ Plant name } & \multicolumn{3}{|c|}{ Location } & \multirow[b]{2}{*}{ Installed capacity MW } & \multirow[b]{2}{*}{ Number of units } & \multirow[b]{2}{*}{ Year installed } \\
\hline & State & Local government & Town & & & \\
\hline Ibom Power & Akawa Ibom & Ikot Abasi & Ikot Abasi & 188 & 4 & December 2009 \\
\hline Ikot Abasi & Akwa Ibom & Ikot Abasi & Ikot Abasi & 300 & 4 & 2013 \\
\hline Gbaran/Ubie & Bayelsa & Yenagoa & Gbaran & 225 & 4 & 2013 \\
\hline Sapele & Delta & Sapele & Ogorode & 1020 & 6 & 2012 \\
\hline Delta & Delta & Ughelli south & Ughelli & 912 & 6 & 2012 \\
\hline NNPC/Agip & Delta & Ndokwa east & Okpai & 480 & 6 & 2005 \\
\hline Egbema Power Plant & Imo & Ohaji/Egbema & Egbema & 338 & 4 & 1990 \\
\hline Ajaokuta & Kogi & Ajaokuta & Ajaokuta & 110 & 4 & 1986 \\
\hline Geregu & Kogi & Ajaokuta & Geregu & 414 & 4 & 2013 \\
\hline Dangote obajana & Kogi & Kabba Bunu & Obajana & 350 & 4 & 2008 \\
\hline Egbin & Lagos & Ikorodu & Ikorodu & 1320 & 6 & 1986 \\
\hline Egbin AES & Lagos & Somolu & Somolu & 270 & 4 & 2001 \\
\hline ljora & Lagos & Ifelodun apapa & ljora & 40 & 4 & 1983 \\
\hline Ewekoro power & Ogun & Ewekoro & Ewekoro & 12.5 & 4 & 2011 \\
\hline
\end{tabular}

Table 2. Emission factors used in emission computation.

\begin{tabular}{lc}
\hline Parameter & Emission \\
\hline $\mathrm{CO}$ & 180 \\
$\mathrm{NO}_{\mathrm{X}}$ & 301 \\
$\mathrm{PM}$ & 6.78 \\
$\mathrm{SO}_{2}$ & 3.45 \\
$\mathrm{VOCs}$ & 2.09 \\
\hline
\end{tabular}

Source: USEPA (1995) 
Stacks, identified as the major source of air pollutants from the thermal power plants, are point sources and are so treated in this study. The flow and stack parameters including exit velocity $(\mathrm{m} / \mathrm{s})$, discharged temperature $\left({ }^{\circ} \mathrm{K}\right)$, stack diameter $(\mathrm{m})$, and release height $(\mathrm{m})$ required for the dispersion modeling inputs data. The digital map of the study area is required for the modeling. These parameters were then combined with the emission rates in the AERMOD for the ground level concentration for $\mathrm{CO}, \mathrm{NO}_{x}, \mathrm{SO}_{2}, \mathrm{PM}$, and VOCs.

The model was applied to estimate daily averages of pollutants ground-level concentrations. Once the representative days are selected, surface daily averaged concentrations of $\mathrm{CO}, \mathrm{NO}_{x}, \mathrm{SO}_{2}, \mathrm{PM}$, and VOCs were estimated using the AERMOD modeling system. Both the immediate and distant environments of the plants were considered as receptors to air pollutants in this study.

A comprehensive cartesian receptor grid extending to $5 \mathrm{~km}$ from the center of the emission source to the west, east, and the north of the power plant and $5 \mathrm{~km}$ to the south was used in the AERMOD modeling to assess the maximum ground-level pollutant concentrations. All discrete receptors located within $5 \mathrm{~km}$ radius of the studied plant were set in the modeling domain. However, all these parameters were then combined with the emission rates as said earlier in the AERMOD for the ground level concentration. The data inputs were processed through the control pathway to the source pathway, then from the receptor pathway to the meteorological pathway to the terrain grid pathway and to the output pathway where the output results were defined.

\section{Results and discussion}

For the country's thermal power plants, ground-level concentrations of $\mathrm{CO}, \mathrm{NO}_{x}, \mathrm{SO}_{2}, \mathrm{PM}$, and VOC for an averaging period of $24 \mathrm{~h}$ were established in the study as presented in Table 3. Figures 1-5 show the surface plots of the maximum predicted $24-\mathrm{h}$ concentration of the pollutants in the Delta State which has the highest number of thermal plants. The maximum daily ground-level concentrations of CO from the thermal power plants were $31.88-92.79 \mu \mathrm{g} / \mathrm{m}^{3}$ with a mean of 49.45 $\mu \mathrm{g} / \mathrm{m}^{3}$. While the maximum daily ground-level concentrations of $\mathrm{NO}_{x}$ from the plants were 25.19$134.34 \mu \mathrm{g} / \mathrm{m}^{3}$ with a mean of $75.33 \mu \mathrm{g} / \mathrm{m}^{3}$, the maximum PM daily were $0.61-3.91 \mu \mathrm{g} / \mathrm{m}^{3}$ with a mean of $2.0 \mu \mathrm{g} / \mathrm{m}^{3}$. The maximum daily ground level concentrations of $\mathrm{SO}_{2}$ were $0.21-.52 \mu \mathrm{g} / \mathrm{m}^{3}$ with a mean of $0.82 \mu \mathrm{g} / \mathrm{m}^{3}$ and the maximum VOCs daily were $0.19-1.09 \mu \mathrm{g} / \mathrm{m}^{3}$ with a mean of 0.64 $\mu \mathrm{g} / \mathrm{m}^{3}$. From the thermal plants, the minimum of the maximum concentrations was obtained in the Bayelsa state and the maximum in the Delta state. All these ground-level concentrations were obtained at about $0.5 \mathrm{~km}$ and $2.5 \mathrm{~km}$ from the source.

In Akwa Ibom, daily CO was $43.04 \mu \mathrm{g} / \mathrm{m}^{3}$ while $\mathrm{NO}_{x}$ was $54.87 \mu \mathrm{g} / \mathrm{m}^{3}$, with $\mathrm{PM}$ of $2.20 \mu \mathrm{g} / \mathrm{m}^{3}$, $\mathrm{SO}_{2}$ levels of $0.68 \mu \mathrm{g} / \mathrm{m}^{3}$, and VOC levels of $0.52 \mu \mathrm{g} / \mathrm{m}^{3}$. Bayelsa state daily levels of CO, $\mathrm{NO}_{x}, \mathrm{PM}$, $\mathrm{SO}_{2}$, and VOC were $31.88,25.19,1.10,0.94$, and $0.52 \mu \mathrm{g} / \mathrm{m}^{3}$, respectively. The daily concentrations of $\mathrm{CO}, \mathrm{NO}_{x}, \mathrm{PM}, \mathrm{SO}_{2}$, and VOC in the Delta state were 92.79, 134.34, 3.91, 1.36, and $1.09 \mu \mathrm{g} / \mathrm{m}^{3}$, respectively. The maximum daily predicted for $\mathrm{CO}, \mathrm{NO}_{x}, \mathrm{PM}, \mathrm{SO}_{2}$, and $\mathrm{VOC}$ in the Imo state were 53.36, 73.93, 3.27, 1.52 , and $0.92 \mu \mathrm{g} / \mathrm{m}^{3}$, respectively.

Table 3. Daily maximum predicted ground-level concentration from the existing thermal power plant in Nigeria.

\begin{tabular}{lccccc} 
& \multicolumn{4}{c}{ Pollutant concentration $\left(\mu \mathrm{g} / \mathrm{m}^{3}\right)$} \\
\cline { 2 - 6 } State & $\mathrm{CO}$ & $\mathrm{NO}_{x}$ & $\mathrm{PM}$ & $\mathrm{SO}_{2}$ & VOCs \\
\hline Akwa ibom & 43.04 & 54.87 & 2.20 & 0.68 & 0.52 \\
Bayelsa & 31.88 & 25.19 & 1.10 & 0.94 & 0.59 \\
Delta & 92.79 & 96.34 & 3.91 & 1.36 & 1.09 \\
Imo & 83.36 & 35.33 & 3.27 & 1.52 & 0.92 \\
Kogi & 46.82 & 95.41 & 0.61 & 0.21 & 0.19 \\
Lagos & 56.64 & 61.33 & 2.54 & 0.94 & 0.93 \\
Ogun & 37.86 & 67.99 & 1.34 & 0.52 & 0.44 \\
Ondo & 38.99 & & & 0.67 & 0.56 \\
\hline
\end{tabular}




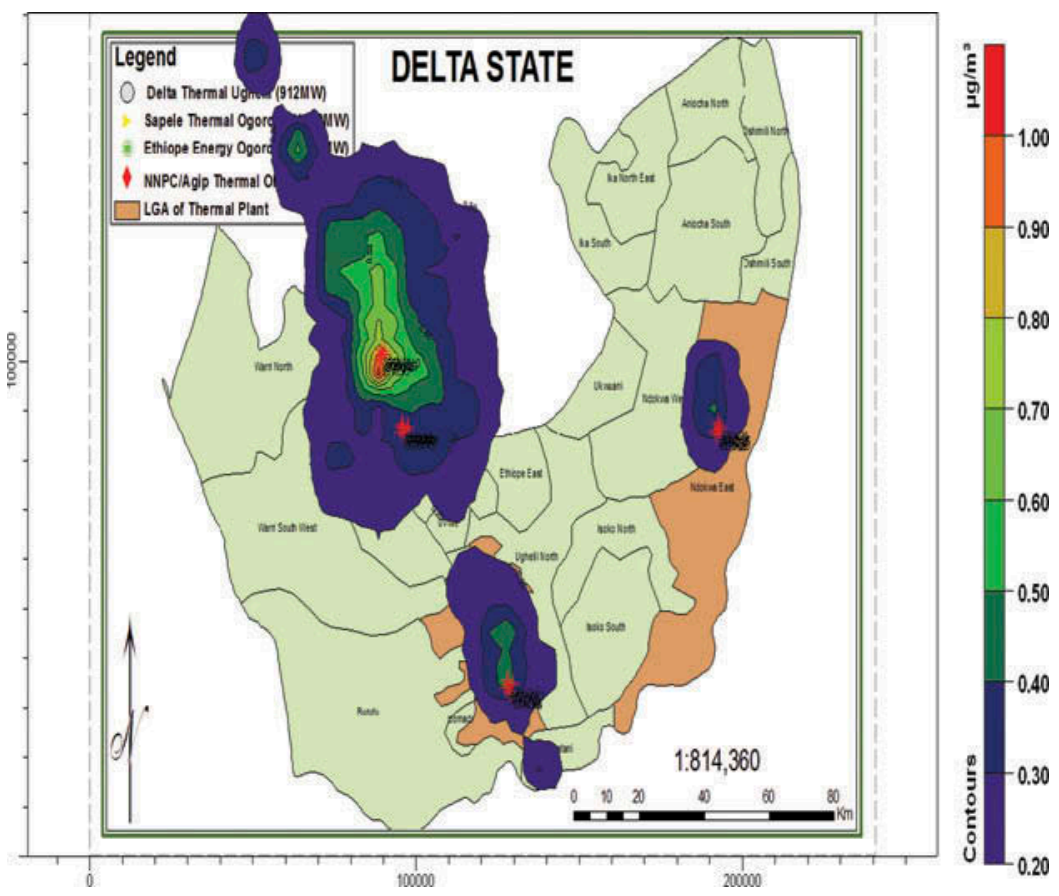

Figure 1. Daily ground-level concentration of CO from TPP in the Delta state.

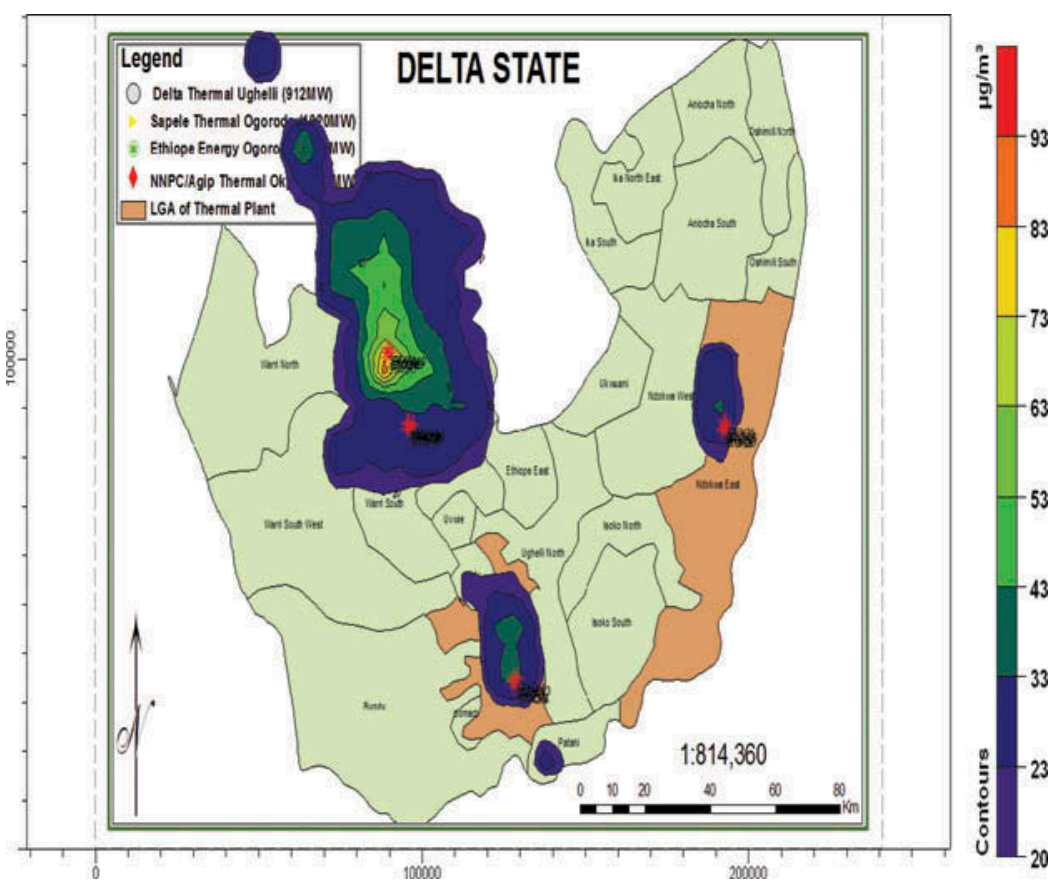

Figure 2. Daily ground-level concentration of nitrogen oxides from TPP in the Delta state. 


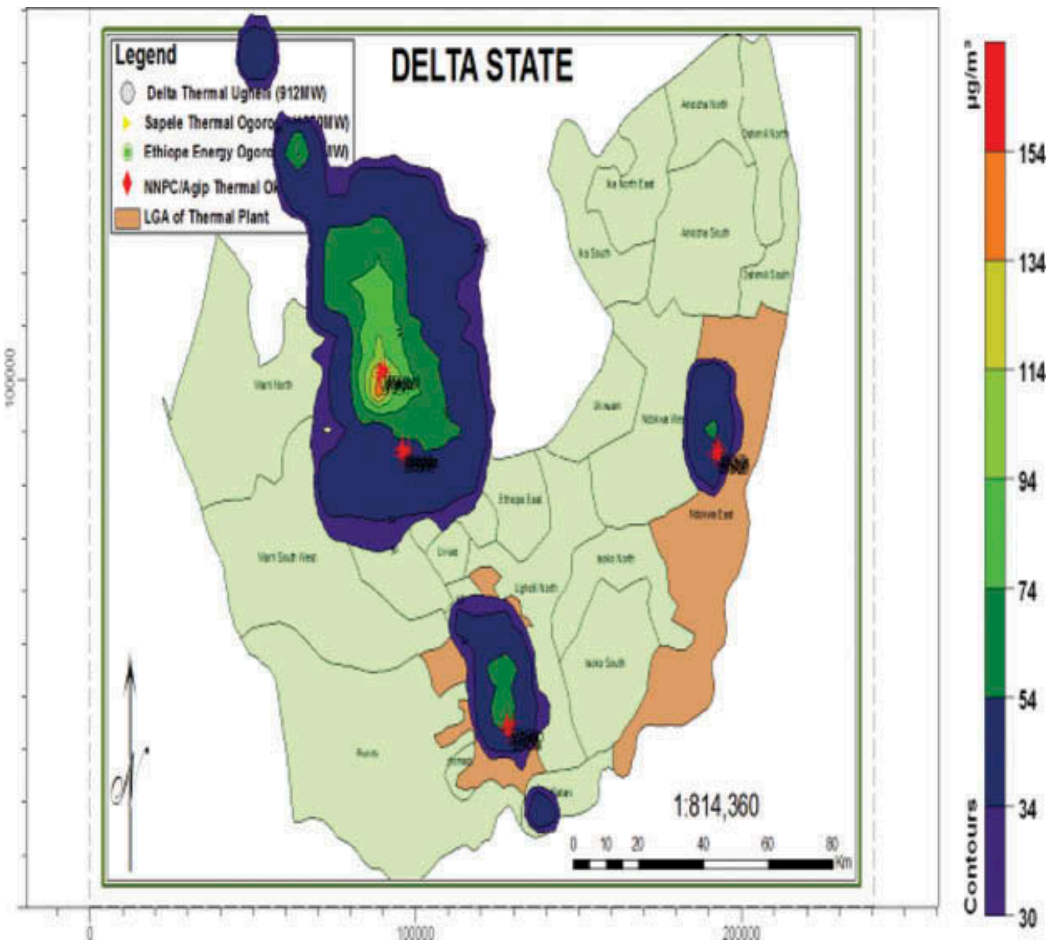

Figure 3. Daily ground-level concentration of particulate matter from TPP in the Delta state.

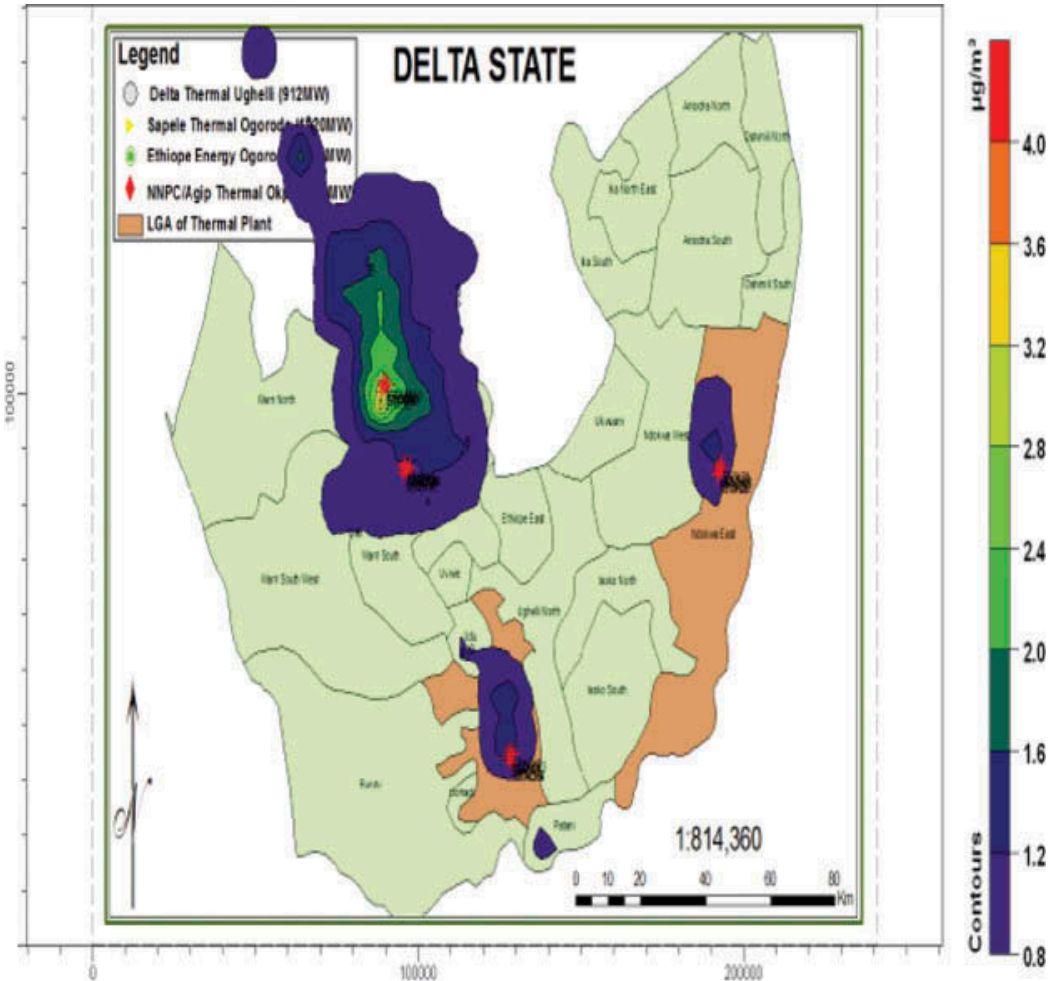

Figure 4. Daily ground-level concentration of sulfur dioxide from TPP in the Delta state. 


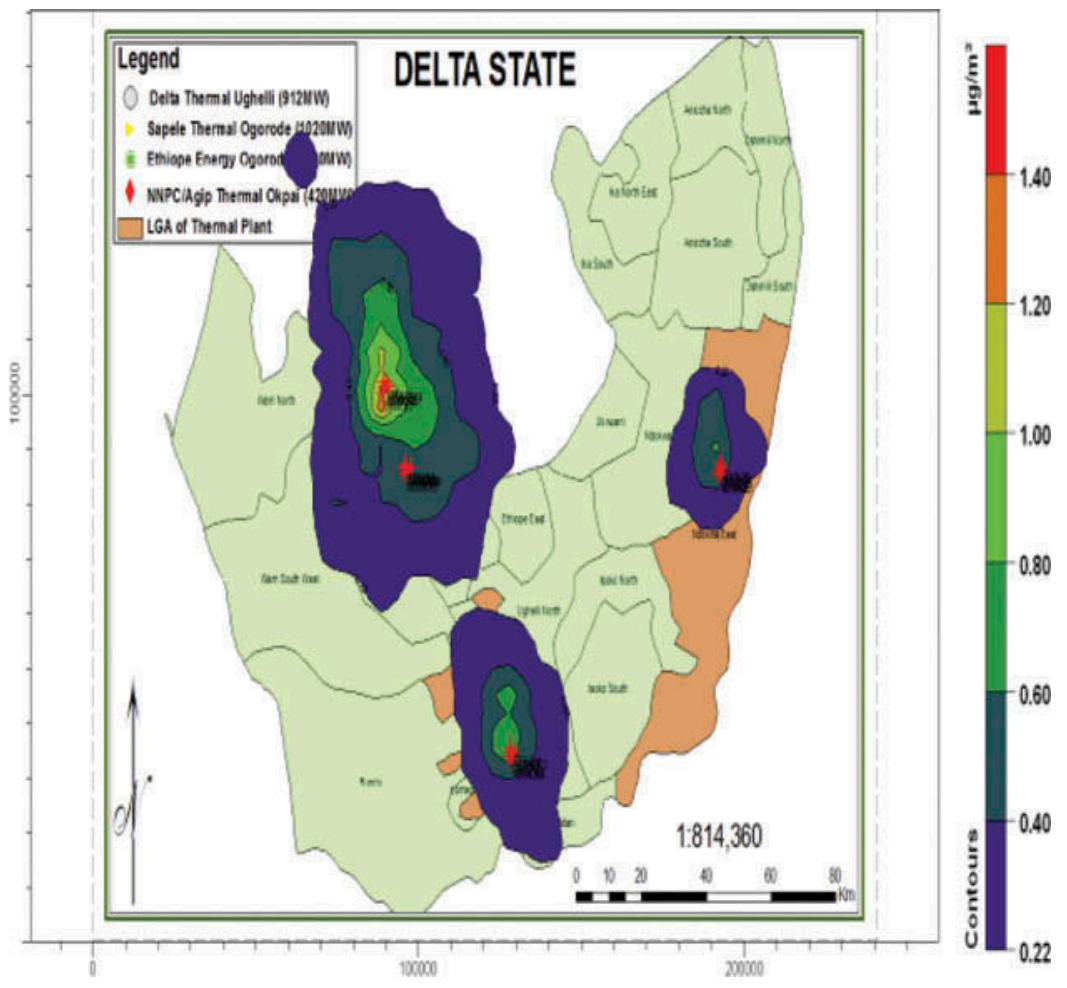

Figure 5. Daily ground-level concentration of volatile organic compounds from TPP in the Delta state.

In the Kogi state, the daily CO was $46.82 \mu \mathrm{g} / \mathrm{m}^{3}$ while $\mathrm{NO}_{x}$ was $35.33 \mu \mathrm{g} / \mathrm{m}^{3}$, with $\mathrm{PM}$ of $2.20 \mu \mathrm{g} / \mathrm{m}^{3}$, $\mathrm{SO}_{2}$ levels of $0.68 \mu \mathrm{g} / \mathrm{m}^{3}$ and VOC levels of $0.52 \mu \mathrm{g} / \mathrm{m}^{3}$. The daily concentrations of CO, $\mathrm{NO}_{x}, \mathrm{PM}, \mathrm{SO}_{2}$, and VOC in the Lagos state were 56.64, 95.41, 2.54, 0.94, and $0.93 \mu \mathrm{g} / \mathrm{m}^{3}$, respectively. The daily groundlevel $\mathrm{CO}, \mathrm{NO}_{x}, \mathrm{PM}, \mathrm{SO}_{2}$, and VOC from the thermal power plants in the Ogun State were 37.86, 61.33, $1.34,0.52$, and $0.44 \mu \mathrm{g} / \mathrm{m}^{3}$, respectively.

The Ondo state experienced daily $\mathrm{CO}, \mathrm{NO}_{x}, \mathrm{PM}, \mathrm{SO}_{2}$, and VOC ground level of $38.99,67.99,1.46$, $1.38,0.57$, and $0.49 \mu \mathrm{g} / \mathrm{m}^{3}$, respectively. The Rivers State daily ground level of CO was $43.67 \mu \mathrm{g} / \mathrm{m}^{3}$ while $\mathrm{NO}_{x}$ was $72.58 \mu \mathrm{g} / \mathrm{m}^{3}$, with PM of $1.54 \mu \mathrm{g} / \mathrm{m}^{3}, \mathrm{SO}_{2}$ levels of $0.57 \mu \mathrm{g} / \mathrm{m}^{3}$, and VOC levels of $0.49 \mu \mathrm{g} / \mathrm{m}^{3}$. The impacts of the thermal electricity power generation activity air emissions on ambient air quality in airshed were investigated by comparing the daily maximum ground-level concentrations of each of the investigated air pollutants with their National Ambient Air Quality Standard (NAAQS) recommended limits, the daily maximum emitted $\mathrm{CO}$ from the thermal electricity power generation activities in the country investigated was $0.43 \%$ of the $11,400 \mu \mathrm{g} / \mathrm{m}^{3}$ daily limit. While the daily maximum $\mathrm{NO}_{x}$ was $66.0 \%$ of the $113 \mu \mathrm{g} / \mathrm{m}^{3}$ limit, the daily maximum PM was $0.8 \%$ of the $250 \mu \mathrm{g} / \mathrm{m}^{3}$ limit. The daily maximum $\mathrm{SO}_{2}$ from the thermal electricity power generation was $3.1 \%$ of the $26 \mu \mathrm{g} / \mathrm{m}^{3}$ limit and VOCs was $3.2 \%$ of $20 \mu \mathrm{g} / \mathrm{m}^{3}$.

Since emissions are directly proportional to the generation capacities, the higher the generation capacities the higher the volume of fossil fuel required (natural gas) for combustion, hence, the higher the ground-level concentration predicted. The Bayelsa state with least generation capacities has the lowest predicted concentration of the pollutants while the Delta state with the highest capacities has the higher concentrations. The color scales in the plot files indicate the various concentrations obtained up to the predicted maximum concentration. 


\section{Conclusion}

In this study, AERMOD has been used to estimate the ground-level concentrations of criteria air pollutants from the thermal power plants in the country. The contribution of these emissions from the thermal power plants to the national emission levels was also established. The maximum daily ground-level concentrations of criteria air pollutant at all receptors were observed to be well below the allowable limit. Emissions predicted from thermal power plants were at the peak in the Delta State and at the lowest levels in the Bayelsa State. The findings indicate that there is a need to quantify the effects of the emissions from thermal power plants in the country. The national electricity regulation commission of Nigeria should make it very compulsory for proposed plants to carry out proper environmental impact assessment before the approval. Host communities should be declared as a protected area with proper monitoring of ground-level concentration of pollutants. Finally, the predicted results of this study will assist the decision makers to formulate policy for controlling the impact of emission from thermal power plants.

\section{ORCID}

B. S. Fakinle (D) http://orcid.org/0000-0002-1465-7850

\section{References}

Essien, A. U., and Igweonu, E. I. 2014. Coal based generation: A solution to Nigeria's electricity problem. Int. Arch. Appl. Sci. Technol. 5:74-80.

EPA. 1995. Compilation of Air pollutants Emission factors, 5th Ed. Stationary, Point and Area sources, Vol. 1. Research Triangle Park, NC, USA: United States Environmental Protection Agency, Office of Air Quality Planning and standards.

Kouprianov, V. I., Bashkin, V. N., Towprayoon, S., Milindalekha, J., and Wongyai, K. 2002. Emission of arsenic and gaseous pollutants from power generation in Northern Thailand: Impact on ecosystems and human health. World Resour. Rev. 14:98-115.

Olugbenga, T. K., Jumah, A. A., and Philip, D. A. 2013. The current and future challenges of electricity market in Nigeria in the face of deregulation process. Afr. J. Eng. Res. 1:33-39.

Sonibare, J. A. 2010. Air Pollution implications of Nigeria's present strategy on improved electricity generation. Energy Policy 38:5783-5789.

Sonibare, J. A., Adeniran, J. A., Fakinle, B. S., Jimoda, L. A., Olu-Arotiowa, O. A., and Latinwo, I. O. 2014. Ambient noise from Off-Grid diesel engines electric power generators in an urban environment. Manage. Environ. Qual. Int. J. 25:186-199.

Sonibare, J. A., and Akeredolu, F. A. (2006). Natural gas domestic market development for total elimination of routine flares in Nigeria's upstream petroleum operations. Energy Policy 34:743-753.

Pokale, W. K. 2012. Effect of thermal power plants on environment review of recent epidemiological evidence. Inhalation Toxicol. 19:33-38. 